\title{
HUBUNGAN ANTARA DUKUNGAN SOSIAL DARI ORANG TUA DENGAN PENYESUAIAN DIRI SANTRI PONDOK PESANTREN ANNUR 2 AL MURTADLO MALANG
}

\author{
Apprillia Mega \\ Fakultas Psikologi \\ Universitas Islam Negeri (UIN) Maulana Malik Ibrahim Malang \\ Jl. Gajayana 50 Malang Telp. 0341-558916
}

\begin{abstract}
Abstrak - Penelitian ini bertujuan mengetahui hubungan tingkat dukungan sosial dari orang tua dengan tingkat penyesuaian diri santri Pondok Pesantren Annur 2 Al Murtadlo Malang. Metode penelitian adalah korelasional kuantitatif. Pengambilan sampel diperoleh secara purposive dan random sampling adalah 68 orang. Pengumpulan data menggunakan metode kuesioner dengan skala Likert. Skala Penyesuaian diri berjumlah 35 aitem dengan reliabilitas $\alpha=, 959$, angket dukungan sosial berjumlah 30 aitem dengan reliabilitas $\alpha=, 949$. Teknik analisis menggunakan korelasi Product Moment. Hasil korelasi diketahui nilai $r_{\text {hit }}$ adalah -0.193 dan nilai $r$ table adalah 0,115. Hubungan Korelasi dikatakan signifikan apabila $r_{\text {hit }}$ lebih besar dari pada $r_{\text {table }}$. Penelitian ini ditemukan bahwa $r_{\text {table }}$ lebih besar dari pada $r_{\text {hit }}$, maka disimpulkan bahwa hasil korelasi tidak mempunyai hubungan. Maka hasil penelitian ini adalah tidak ada hubungan antara dukungan sosial dari orang tua dengan penyesuaian diri santri remaja.
\end{abstract}

Kata Kunci: Dukungan sosial, Penyesuaian diri

PSIKOISLAMIKA. Jurnal Psikologi Islam (JPI) copyright @ 2013 Laboratorium Penelitian, Kajian Psikologi Islam dan Penerbitan. Volume 10. Nomor 2, Tahun 2013

\section{PENDAHULUAN}

Tahap perkembangan remaja memiliki kharakteristik yang unik diantaranya mengalami perkembangan fisik disertai perubahan bentuk tubuh yang drastis, dan dibarengi dengan perkembangan mental serta kognitif yang berkembang cukup pesat. Dari sinilah remaja dituntut untuk beradaptasi terhadap perubahan tersebut dan dibutuhkannya penyesuaian mental, penanaman moral secara benar dan penyesuaian terhadap minat-minat disekitarnya. Disinilah status individu remaja menjadi tidak jelas, jika remaja berperilaku seperti anak kecil akan mendapat teguran dan jika remaja berperilaku seperti orang dewasa dianggap kurang pantas. Kewajiban untuk tinggal di lingkungan pondok pesantren menuntut santri menyesuaikan diri terhadap segala aktifitas, budaya dan kebiasaan yang ada di lingkungan pesantren. Sebagaimana penyesuaian diri menurut Syamsu yusuf (2007) diartikan sebagai suatu proses yang melibatkan respon-respon mental dan perbuatan individu dalam rangka memenuhi berbagai kebutuhannya, serta mengatasi ketegangan, frustasi dan konflik dengan memperhatikan norma-norma lingkungan tempat dia hidup. Remaja dengan dinamika khas pertumbuhan dan tugas perkembangannya tertuntut untuk menyesuaikan diri terhadap berbagai kondisi dan pengalaman yang mereka alami dalam lingkup kehidupan pondok pesantren. Penelitian mengenai penyesuaian diri di lingkungan pondok pesantren sebelumnya telah di adakan oleh Mufidatul Munawaroh pada tahun 2009 dengan judul Hubungan antara Motivasi Belajar dengan Penyesuaian Diri Santri Baru Pondok Pesantren Putri Al Islahiyah Singosari, hasil dari penelitian tersebut adalah adanya hubungan positif antara motivasi belajar dengan penyesuaian diri sebesar $40 \%$. 
Masing-masing remaja dalam dinamika penyesuaian diri memiliki kemampuan menyesuaikan diri yang berbeda. Hasil wawancara terhadap ustadz mengenai keadaan santri menyebutkan, terdapat salah satu santri ketika santri memiliki permasalahan yang dirasa sulit, santri tersebut meninggalkan pondok pesantren untuk pulang kerumahnya tanpa izin pengurus. Perilaku tersebut merupakan dinamika penyesuaian diri remaja yang perlu mendapat perhatian dari pihak yang berkaitan. Dari uraian permasalahan remaja tersebut, dapat kita ketahui bahwa remaja dalam melakukan penyesuaian diri untuk hidup di lingkungan pesantren membutuhkan bantuan dan dukungan secara emosi dan materi seperti dari orang tua, keluarga, kerabat, teman dekat, masyarakat, ustadz dan orang-orang dekat lain di sekitar mereka. Menurut Diamtteo (2009) dukungan atau bantuan yang berasal dari orang lain seperti teman, keluarga, tetangga, teman kerja dan orang-orang lainnya merupakan definisi dukungan sosial (sosial support). Orang tua memiliki kewajiban memberi kasih sayang kepada anak, mengembangkan kepribadian anak, menanamkan rasa tanggung jawab kepada anak, serta mengajarkan agama dan system moral pada anak-anaknya. Penelitian mengenai dukungan sosial orang tua pernah dilakukan oleh Irmiwati dwi febrianti pada tahun 2009 dengan judul penelitian Hubungan antara Dukungan Sosial Orang tua dengan Prokrastinasi Akademik dalam Menyelesaikan Skripsi pada Mahasiswa Fakultas Psikologi Universitas Diponegoro Semarang dengan hasil penelitian bahwa dukungan sosial orang tua memberi sumbangan efektif sebesar 13,9\% terhadap Prokrastinasi Akademik dalam Menyelesaikan Skripsi pada Mahasiswa Fakultas Psikologi Universitas Diponegoro Semarang.

Remaja yang mengadakan penyesuaikan diri pada kehidupan pondok pesantren tentunya masih membutuhkan dukungan baik secara emosi dan materi dari orang tua selaku orang dewasa dalam keluarga. Orang tua dalam memberikan dukungan sosial dapat memberikan saran yang baik kepada santri dalam menyesuaikan diri pada kehidupan pondok pesantren, orang tua diharap memenuhi kebutuhan kehidupan remaja secara proposional kepada remaja, orang tua memenuhi kebutuhan belajar remaja, serta senantiasa memberikan nasihat untuk remaja dan lain sebagainya. Mengingat permasalahan penyesuaian diri remaja terhadap kehidupan selama di pondok pesantren yang penting untuk diperhatikan demi terciptanya suasana belajar yang lebih kondusif untuk remaja seperti yang telah disebutkan diatas. Atas dasar hal tersebut maka peneliti mengadakan penelitian dengan judul Hubungan Dukungan Sosial dari Orang tua dengan Penyesuaian Diri Santri Pondok Pesantren Annur 2 Al Murtadlo Malang.

\section{KERANGKA KERJA TEORITIK}

Kuntjoro (2010) menyebutkan bahwa dukungan sosial merupakan bantuan atau dukungan yang diterima individu dari orang-orang dalam kehidupannya yang berada dalam lingkungan sosial tertentu sehingga individu penerima merasa diperhatikan, dihargai dan dicintai. Rock (2010) mengatakan bahwa dukungan sosial merupakan salah satu fungsi dari ikatan sosial, ikatan- ikatan sosial tersebut menggambarkan tingkat kualitas umum dari hubungan interpersonal. Dukungan sosial yang diterima dapat membuat individu merasa tenang, diperhatikan, dicintai, timbul rasa percaya diri dan kompeten. Jadi dari pemaparan dari para ahli diatas maka persepsi individu penerima bantuan menjadi faktor yang penting dari dukungan sosial.

Sumber-sumber dukungan sosial menurut Kahn \& Antonoucci (2009) terbagi menjadi 3 kategori, yaitu: pertama, sumber dukungan sosial yang berasal dari individu yang selalu ada sepanjang hidupnya, yang selalu bersama dan mendukungnya. Misalnya orang tua, keluarga dekat, pasangan hidup atau teman-teman dekat. Kedua, sumber dukungan sosial yang berasal dari individu lain yang sedikit berperan dalam hidupnya dan cenderung berubah sesuai dengan waktu. Sumber ini meliputi teman kerja, tetangga, sanak keluarga dan sepergaulan. Ketiga, sumber dukungan sosial yang berasal dari individu lain yang sangat jarang memberi dukungan sosial dan memiliki peran yang sangat cepat berubah. Sumber dukungan yang dimaksud meliuputi supervisor, tenaga ahli atau profesional dan keluarga jauh.

Sumber utama dukungan sosial adalah orangorang terdekat individu yang selalu hidup bersama dengan individu seperti orang tua, keluarga, pasangan hidup dan teman-teman dekat. Peletak dasar hubungan sosial anak adalah hubungan orang tua dengan anak, dimana orang tua memiliki peran penting dalam keluarga sebagai orang dewasa yang memberikan rasa aman, kasih sayang, perlindungan, dan pendidikan. Santrock (2009) menjelaskan bahwa orang tua berperan sebagai tokoh penting dengan siapa anak menjalin hubungan dan merupakan suatu system dukungan ketika anak menjajaki suatu dunia sosial yang lebih luas dan 
kompleks. Maka dukungan sosial orang tua yaitu segala bentuk bantuan yang diberikan oleh orang tua, yang kemudian di persepsi oleh anak secara subjektif dimana anak merasa puas dengan bantuan yang di berikan oleh orang tuanya.

\section{Indikator Dukungan Sosial Orang Tua}

Irnawati (2009) menyebutkan bahwa menurut Weis terdapat enam komponen atau aspek yang kemudian dikembangkan menjadi "Sosial Provisions Scale" untuk mengukur ketersediaan dukungan sosial yang diperoleh dari hubungan individu dengan orang lain. Enam komponen atau aspek tersebut antara lain: Attachment, Sosial integration, Reasurance of worth), Reliable alliance, Guidance, Opportunity for nuturance.

a) Attachment, aspek dukungan kasih sayang yang diberikan kepada individu memberikan adanya perasaan kedekatan emosional, rasa aman, tentram, damai bagi penerima. Bentuk kasih sayang orangtua terhadap remaja diantara : orangtua mampu menghibur ketika remaja mengalami permasalahan, orangtua mampu memahami dan bersikap baik terhadap kondisi remaja, orangtua memberikan perhatian ketika anak sedang sakit, dan orangtua mampu memahami perasaan remaja.

b) Sosial integration, merupakan perasaan menjadi bagian dari kelompok, tempat berbagi minat, perhatian, serta melakukan kegiatan yang menyenangkan bersama-sama. Bentuk integrasi sosial hubungan antara orangtua dengan remaja yang tinggal di pondok pesantren diantaranya: orangtua memberi kesempatan pada remaja untuk tetap memiliki peran dalam memutuskan permasalahan dalam keluarga walaupun remaja tinggal jauh dari keluarga, orangtua selalu siap untuk membantu dan mencurahkan perhatian kepada anak, orangtua memiliki kesempatan untuk berbagi suka dan duka dengan anak, dan orangtua mempercayakan pada remaja untuk membantu permasalahan yang sedang dialami oleh orangtua.

c) Reasurance of worth, Individu mendapatkan pengakuan atas kemampuan dan minatnya dari oranglain. Contohnya, orangtua memberi pujian atas perilaku positif remaja, orangtua mampu memberikan respon positif terhadap pendapat remaja, orangtua mengapresiasi minat positif remaja, dan orangtua tetap memberikan kepercayaan kepada remaja atas usaha yang akan dilakukan remaja. d) Reliable alliance, individu mendapatkan kepastian atau jaminan bahwa individu dapat mengharapkan oranglain untuk membantu dalam semua keadaan. Bentuk ikatan yang dapat diandalkan remaja kepada orangtua misalnya, remaja mampu terbuka kepada orangtua, remaja merasa lebih nyaman dengan bercerita baik suka maupun duka dengan orangtua, dan orangtua mampu memberikan motivasi positif pada usaha remaja dalam penyesuaian dirinya seperti menumbuhkan rasa percaya diri remaja ketika remaja merasa dirinya kurang berharga, meningkatkan minat remaja ketika remaja merasa kurang berarti dan lain sebagainya.

e) Guidance, adanya hubungan sosial atau juga hubungan kerja yang memungkinkan individu mendapatkan nasehat, saran dan pemberian informasi yang diperlukan untuk memenuhi kebutuhan dalam mengatasi permasalahan yang sedang dihadapi. Bentuk bimbingan atau nasihat yang dapat diberikan oleh orangtua kepada remaja adalah dengan memberika solusi atau saran yang bijaksana untuk remaja ketika remaja bimbang terhadap permasalahannya, orangtua membantu remaja untuk membuat keputusan yang bijak ketika diminta oleh remaja, orangtua memberikan teguran positif yang mampu membangun perilaku positif remaja ketika remaja berperilaku kurang sopan, dan lain-lain.

f) Opportunity for nuturance, dengan adanya kesempatan untuk membantu, individu merasa dirinya dibutuhkan dan penting bagi orang lain sehingga individu dapat merasa lebih berharga dan bernilai. Bentuk kesempatan remaja untuk membantu orangtua misalnya dengan orangtua memberikan kepercayaan kepada remaja untuk memberikan solusi kepada permasalahan orangtua, orangtua mampu terbuka dengan saling membicarakan permasalahan yang terjadi yang kiranya remaja mampu membantu orangtua, remaja mampu menjadi pendengar yang baik ketika orangtua berkeluh kesah dan lain sebagainya.

Berdasarkan penjelasan tersebut diatas maka dalam penelitian ini peneliti menggunakan indikator dukungan sosial dari aspek yang telah dijelaskan oleh Weis dalam "Sosial Provision Scale".

\section{Penyesuaian Diri Remaja}

Calhoun dan Acocella (1995) mengatakan bahwa penyesuaian dapat didefinisikan sebagai 
interaksi seseorang yang kontiniu dengan diri sendiri, dengan orang lain, dan dengan lingkungannya. Mustofa (2009) mendefinisikan penyesuaian diri dalam ilmu jiwa adalah proses dinamika yang bertujuan untuk mengubah tingkah laku sepaya terjadi hubungan yang dinamis antara individu dan lingkungannya. Menurut Fahmi (2003), penyesuaian adalah suatu proses dinamika terus menerus yang lebih disertai antara diri dan lingkungan.

Menurut Mohammad Ali (2006), penyesuaian diri dapat diartikan sebagai suatu proses yang mencangkup respon-respon mental dan behavioral yang diperjuangkan individu agar dapat berasil menghadapi kebutuhan-kebutuhan internal, ketgangan, frustasi, konflik, serta untuk menghasilkan kualitas keselarasan antara tuntujan dari dalam diri individu dengan tntutan dunia luar atau lingkungan tempat individu berada. Dari beberapa teori dapat disimpulkan bahwa penyesuaian diri merupakan kemampuann individu dalam proses pemenuhan kebutuhan diri terhadap tuntuta internal diri dan lingkungan di luar diri,untuk mendapatkan keselarasan hidup dan berperilaku.

\section{Indikator Penyesuaian Diri Remaja}

Beberapa karakteristik penyesuaian diri pada remaja menurut Ali (2006), yaitu:

a) Penyesuaian diri remaja terhadap peran dan identitasnya

Masa remaja disebut pula masa peralihan, remaja beralih dari masa kanak-kanak ke dewasa. Peran individu pada masa remaja, di tuntut untuk meninggalkan perilaku atau sikap yang seperti anak-anak untuk bersikap lebih dewasa. Masa remaja juga merupakan masa mencari identitas, dalam proses tersebut remaja lebih mengutamakan penyesuaian dirinya terhadap kelompok teman sebaya dari pada individualitas, karena dari teman sebayalah ia merasa mendapat pengakuan peran dan identitasnya.

b) Penyesuaian diri remaja terhadap Pendidikan

Umumnya remaja menyadari bahwa untuk meraih kesuksesan ia wajib belajar dengan baik. Penyesuaian diri remaja yang khas berjuang ingin meraih sukses dalam studi, tetapi dengan cara-cara yang menimbulkan perasaan bebas dan senang, terhindar dari tekanan dan konflik, atau bahkan frustasi.

c) Penyesuaian diri remaja terhadap kehidupan seks
Secara fisiologis remaja telah mengalami kematangan fungsi seksual, sehingga minat terhadap seks pun meningkat. Jadi, secara khas penyesuaian diri remaja dalam konteks ini adalah mereka ingin memahami kondisi seksual dirinya dan lawan jenisnya serta mampu bertindak untuk menyalurkan dorongan seksualnya yang dapat dimengerti dan di benarkan oleh norma sosial dan agama.

d) Penyesuaian diri remaja terhadap Norma sosial

Adanya norma, nilai-nilai moral, adat istiadat, hukum, dan situasi sosial yang ada, menyebabkan remaja memiliki tugas untuk beradaptasi dengan mengembangkan perilaku sosial kearah yang lebih bertanggung jawab. Remaja menyadari adanya norma yang membedakan nilai baik dan buruk, di sisi lain remaja dan kelompok teman sebaya membuat nilai-nilai dan aturan tersendiri di dalam kelompoknya. Apabila terdapat pertentangan antara nilai kelompok dengan nilai sosial yang ada dalam masyarakat, remaja cenderung untuk memilih norma kelompok yang menurutnya akan menjadi dukungan sosial yang paling berpengaruh dalam proses pembentukan identitas sosial. Andi Mappiare (1882) menyebutkan keadaan pribadi, sosial dan moral remaja pada masa perkembangan yang demikian berada dalam periode yang kritis atau "critical period" atau periode kritis. Dalam konteks ini, penyesuaian diri remaja terhadap norma sosial mengarah pada dua dimensi, pertama, remaja ingin diakui keberadaannya dalam masyarakat luas, yang berarti remaja harus mampu menginternalisasikan nilai-nilai yang berlaku di masyarakat. Kedua, remaja ingin bebas menciptakan aturan-aturan tersendiri yang lebih sesuai untuk kelompoknya, tetapi menuntut agar dapat dimengerti dan diterima oleh masyarakat dewasa.

e) Penyesuaian diri remaja terhadap penggunaan waktu luang

Waktu luang remaja merupakan kesempatan untuk memenuhi dorongan bertindak bebas. Namun disisi lain, remaja dituntut untuk mampu menggunakan waktu luangnya untuk kegiatan-kegiatan yang bermanfaat bagi dirinya maupun orang lain. Upaya penyesuaian diri remaja terhadap penggunaan waktu luang adalah melakukan penyesuaian antara dorongan kebebasannya serta inisiatif dan kreativitasnya dengan kegiatan-kegiatan yang bermanfaat. 
f) Penyesuaian diri remaja terhadap penggunaan uang

Untuk memenuhi dorongan sosialnya remaja membutuhkan bantuan financial, remaja belum sepenuhnya mandiri untuk masalah finansial maka remaja dibantu orang tua untuk memenuhi kebutuhan finansialnya sesuai dengan kemampuan keluarga. Kesempatan, kegiatan, hobi, minat, dan kebutuhan tuntutan sosial kelompok teman sebaya terkadang menyebabkan melonjaknya kebutuhan financial remaja sehingga uang yang diterima dari orang tua dirasa kurang utuk memenuhi kebutuhan tersebut. Disinilah penyesuaian diri remaja terhadap penggunaan uang, remaja sebaiknya mampu belajar untuk proposional dalam penggunaan uang dan pemenuhan kebutuhan, sesuai dengan kemampuan keluarga. Dengan begitu diharapkan tidak terjadi adanya keguncangan, konflik atau frustasi remaja.

g) Penyesuaian diri remaja terhadap kecemasan, konflik dan frustasi

Banyak remaja merasakan sulitnya menyelesaikan permasalahan-permasalahan yang terjadi dalam kehidupannya. Menurut Hurlock, terdapat dua alasan bagi kesulitan itu. Pertama, sepanjang masa kanak-kanak, masalah anak-anak sebagian diselesaikan oleh orang tua dan guru-guru, sehingga kebanyakan remaja tidak berpengalaman dalam mengatasi masalah. Kedua, karena para remaja merasa diri mandiri, sehingga mereka ingin mengatasi masalahnya sendiri, menolak bantuan orang tua dan guru-guru. Konflik sering kali di alami oleh para remaja, baik konflik batin maupun konflik sosial remaja. Gangguan kecemasan pun juga pasti pernah dialami oleh setiap remaja, bahkan beberapa remaja mengalami frustasi kaena permasalahan-permasalahan yang sedang ia alami. Disinilah para remaja belajar menyesuaikan diri terhadap keadaan dan mencoba berbagai cara mengatasi permasalahan-permasalah tersebut.

Hubungan Dukungan Sosial Orang tua dengan Penyesuaian Diri Remaja Pondok Pesantren Annur 2 Malang

Remaja yang tinggal di lingkungan pendidikan pesantren perlu menyesuaikan dirinya dengan karakteristik lingkungan pesantren. Tugas perkembangan pada remaja di fokuskan pada upaya menghilangkan sikap dan perilaku yang kekanak-kanakan untuk mencapai kemampuan bersikap dan berperilaku secara dewasa. Sehingga seringkali remaja menunjukkan sikap dan perilaku yang gelisah, kebingungan, karena terjadi berbagai pertentangan kehidupan yang ia temui. Untuk itu, remaja masih memerlukan keteladanan, konsistensi, komunikasi dan perhatian yang tulus dari orang dewasa. Orang tua sebagai manusia dewasa dalam keluarga menjadi sumber dukungan sosial yang penting bagi anak yang sedang menginjak usia remaja.

Kehangatan dan keeratan hubungan sosial individu dengan keluarga masih sangat dirasa oleh remaja walaupun ia bertempat tinggal jauh dari keluarga. Dukungan sosial orang tua merupakan persepsi anak terhadap segala bantuan yang di berikan oleh orang tua baik bantuan berupa emosional maupun materiil. Dalam menafsirkan suatu kejadian atau situasi, persepsi setiap individu dapat berbeda, tergantung pada bagaimana individu tersebut mengamati dan menanggapinya. Berdasarkan apa yang telah di uraikan diatas maka dapat di ketahui bahwa memungkinkan adanya hubungan dukungan sosial orang tua dengan penyesuaian diri remaja yang tinggal di Pondok Pesantren Annur 2 Malang.

Berdasarkan uraian tersebut hipotesis yang diajukan dalam penelitian ini adalah ada hubungan yang positif antara dukungan sosial dari orang tua sebagai variabel $X$ dengan penyesuaian santri remaja sebagai variable $\mathrm{Y}$.

\section{METODE}

Berdasarkan metodenya penelitian ini adalah correlation studies yang bertujuan untuk mengetahui hubungan antar variabel yang diteliti, antara variable pertama dan kedua terdapat sebab akibat atau dapat diperkirakan keadaan pertama menjadi penyebab keadaan kedua. Jadi penelitian ini adalah penelitian kuantitatif deskriptif yang bersifat korelasional yakni penelitian yang meneliti tentang ada tidaknya hubungan antara variable-variabel yang diteliti. Penelitian dilakukan dengan menghimpun data, menyusun data secara sistematis, faktual dan cermat kemudian melakukan uji hipotesis untuk mengetahui hubungan antar variabel. Dalam penelitian ini variable yang ingin diketahui adalah "hubungan antara dukungan sosial dari orang tua dengan penyesuaian diri remaja". Dalam penelitian ini di tentukan dua jenis variable yakni variable bebas adalah variabel dukungan sosial dari orang tua dan variable terikat adalah penyesuaian diri remaja.

Populasi dalam penelitian ini adalah santri Pondok Pesantren Annur 2 AL Murtadlo yang memenuhi kriteria usia : masa remaja pertengahan $15-18$ 
tahun. Untuk mengetahui tingkat penyesuaian diri remaja maka remaja yang diambil sebagai populasi merupakan santri baru yang terhitung maksimal 1 tahun berada di Pondok Pesantren Annur $2 \mathrm{AL}$ Murtadlo karena diperkirakan pada remaja yang merupakan santri baru memiliki dinamika penyesuaian diri dengan beberapa permasalahannya daripada santri yang telah lebih lama menyesuaikan diri di pondok pesantren. Jumlah populasi yang memenuhi kriteria sebagai berikut remaja usia antara 15 sampai 18 tahun sejumlah 136 orang. Dari jumlah populasi tersebut kemudian menggunakan metode random sampling dengan cara undian. Didapat 68 orang sebagai subyek penelitian.

Metode pengumpulan data pada penelitian ini diperoleh dengan menggunakan metode skala. Menggunakan 2 skala, yaitu Skala dukungan orang tua dan skala penyesuaian diri yang sebelumnya telah dilakukan uji validitas dan realibilitas terhadap skala tersebut. Selanjutnya data yang diperoleh dianalisis dengan menggunakan analisis deskriptif yang digunakan untuk menjelaskan tingkat dukungan sosial orang tua dan tingkat penyesuaian diri santri. Kemudian menlakukan analisis korelasi peneliti menggunakan teknik analisis product moment untuk mengetahui indeks korelasi antara dua variable yang dikorelasikan, nilai korelasi mengandung makna ada tidaknya korelasi. Dalam melakukan perhitungan peneliti menggunakan bantuan program SPSS (Statistical Product and Service Solution) 16.0 for windows.

\section{HASIL}

Tingkat Dukungan Sosial dari orang tua

Berdasarkan hasil analisa dapat diketahui bahwasanya tingkat dukungan sosial dari orang tua santri Pondok Pesantren Annur 2 Al Murtadlo Malang berada dalam kategori tinggi berjumlah 67 responden dengan prosentase $98,5 \%$ dari jumlah responden 68 santri, sedangkan tingkat dukungan sosial dari orang tua dalam kategori sedang jumlah responden 1 santri dengan prosentase $1,5 \%$, kemudian tidak ada responden untuk tingkat dukungan sosial dari orang tua dalam kategori rendah maka prosentase $0 \%$. Hal ini menunjukkan bahwa orangtua sebagian besar santri Pondok Pesantren Annur 2 Al Murtadlo Malang telah memberikan dukungan sosial dengan baik.

\section{Tingkat Penyesuaian Diri Remaja Pondok Pesantren Annur 2 Al Murtadlo}

Berdasarkan hasil analisa dapat diketahui bahwasanya seluruh santri yang menjadi responden yaitu berjumlah 68 santri memiliki tingkat penyesuaian diri tinggi sehingga prosentase tingkat penyesuaian diri tinggi yaitu $100 \%$. Tingkat penyesuaian diri santri dalam kategori sedang berjumlah 0 responden dengan prosentase $0 \%$ dan tingkat penyesuaian diri santri dalam kategori rendah berjumlah 0 responden dengan prosentase $0 \%$. Berdasarkan analisa data, santri yang belum satu tahun tinggal di Pondok Pesantren Annur 2 Al Murtadlo Malang telah mampu mengadakan penyesuaian diri dengan baik, santri memiliki kemampuan dalam proses memenuhi kebutuhan-kebutuhannya baik kebutuhan yang merupakan tuntutan dari internal diri maupun dari lingkungan diluar dirinya.

\section{Hubungan Dukungan Sosial dari Orang tua dengan penyesuaian Diri Remaja Pondok Pesantren Annur 2 Al Murtadlo}

Hasil korelasi diketahui nilai $r_{\text {hit }}$ adalah 0.193 , nilai $r_{\text {table }}$ adalah 0,115. Hubungan Korelasi dikatakan signifikan atau mempunyai hubungan apabila $r$ hitung lebih besar dari pada $r$ table. Dari tabel yang terpapar tersebut, maka dapat diketahui bahwa tidak terdapat hubungan yang signifikan antara Dukungan Sosial dari Orang tua dengan penyesuaian Diri. Jadi, Ho diterima dan $\mathrm{Ha}$ di tolak. Ho diterima maka tidak ada hubungan antara dukungan sosial dari orang tua sebagai variabel $X$ dengan penyesuaian santri remaja sebagai variable Y. Hasil korelasi tersebut menyatakan bahwa tidak ada hubungan antara dukungan sosial dari orang tua sebagai variabel $X$ dengan penyesuaian santri remaja sebagai variable $Y$. Pada penelitian ini hasil analisis korelasi antara Dukungan Sosial dari Orang tua dengan penyesuaian Diri Remaja menyatakan bahwa tidak ada hubungan antara dukungan sosial dari orang tua sebagai variabel $X$ dengan penyesuaian santri remaja sebagai variable $Y$, yang berarti bahwa dukungan sosial dari orang tua tidak mempengaruhi santri remaja dalam melakukan proses penyesuaian diri di pondok pesantren.

Dari hasil penelitian ini didapatkan kesimpulan bahwa tidak ada hubungan antara dukungan sosial dari orang tua dengan penyesuaian diri santri Pondok Pesantren Annur 2 Malang. Hal ini terdapat kesenjangan antara teori yang ada dengan hasil penelitian. Orang tua sebagai individu yang memiliki hubungan dekat dengan remaja tidak memiliki hubungan yang signifikan untuk membantu penyesuaian diri remaja di lingkungan pondok pesantren. Hal ini dapat dikarenakan keseharian santri yang tidak bersama 
orang tua namun bersama teman sebaya dan ustadz sebagai pendamping. Karakteristik perkembangan remaja yang menginginkan otonomy terhadap dirinya juga menjadi penyebab komunikasi antara orang tua dan remaja menjadi jarang terbangun. Hal tersebut terjadi pula pada remaja yang tinggal di pondok pesantren, remaja menginginkan otonomy sehingga komunikasi antara orang tua dan remaja semakin jarang terbangun diluar kesempatan ketika orang tua menjenguk santri di pondok pesantren.

Remaja yang tinggal di pondok pesantren tetap merasakan integrasi sosial dengan orang tua, namun hal tersebut tidak signifikan untuk membantu proses penyesuaian diri santri di lingkungan pondok pesantren. Santri di pondok pesantren diterima baik oleh pengurus dan pengasuh, santri memiliki teman sebaya yang saling membantu dalam proses penyesuaian diri di lingkungan pondok pesantren yang berarti remaja mendapat integrasi sosial dari pengurus, pengasuh dan teman sebaya sehingga memudahkan santri membuka diri untuk mengadakan penyesuaian diri terhadap lingkungan pondok pesantren. Dari hasil penelitian ini, remaja mendapatkan aspek dukungan sosial tersebut dari orang tua namun bantuan dari orang tua tidak signifikan untuk membantu proses penyesuaian diri remaja di lingkungan pondok pesantren Annur $2 \mathrm{Al}$ Murtadlo Malang. Sehingga interaksi dan hubungan yang terbangun antara santri dengan warga pondok pesantren menjadi sumber utama dukungan sosial remaja yang tinggal di pondok pesantren Annur 2 Al Murtadlo yang mampu membantu santri untuk mengadakan penyesuaian diri di lingkungan pondok pesantren.

\section{DAFTAR PUSTAKA}

Abbas, Abdullah bin. 2007. Kiat Mengatasi Strees Anak melalui Sikap Kasih Sayang Orang tua. Jakarta: Restu Agung.

Agustiani, H. 2006. Psikologi Perkembangan; Pendekatan Ekologi Kaitannya dengan Konsep Diri dan Penyesuaian Diri pada Remaja. Bandung: Aditama.

Ali, Muhammad dan Anshory. 2006. Psikologi Remaja Perkembangan Peserta Didik. Jakarta: Bumi Aksara.

Arikunto, Suharsimi. 2006. Prosedur Penelitian Suatu Pendekatan Praktik. Jakarta : Rineka Cipta.

\section{KESIMPULAN}

Berdasarkan pemaparan dan rumusan masalah yang telah dijawab dalam penelitian ini, maka disebutkan beberapa kesimpulan:

1. Tingkat dukungan sosial dari orang tua berada dalam kategori tinggi berjumlah 67 responden dengan prosentase $98,5 \%$ dari jumlah responden 68 santri, sedangkan tingkat dukungan sosial dari orang tua dalam kategori sedang jumlah responden 1 santri dengan prosentase 1,5\%, kemudian tidak ada responden untuk tingkat dukungan sosial dari orang tua dalam kategori rendah maka prosentase $0 \%$.

2. Tingkat Penyesuaian diri berada dalam kategori tinggi berjumlah 68 responden dengan prosentase $100 \%$, tingkat Penyesuaian diri remaja dalam kategori sedang berjumlah 0 responden dengan prosentase $0 \%$ dan tingkat Penyesuaian diri remaja dalam kategori rendah berjumlah 0 responden dengan prosentase $0 \%$

3. Dari hasil korelasi diketahui nilai $r_{\text {hit }}$ adalah - 0.193 sedangkan nilai $r$ table adalah 0,115. Hubungan Korelasi dikatakan signifikan atau mempunyai hubungan apabila $r_{\text {hit }}$ lebih besar dari pada $r_{\text {table }}$. Dalam penelitian ini ditemukan bahwa $r_{\text {table }}$ lebih besar dari pada $r_{\text {hit }}$, maka dapat disimpulkan bahwa hasil korelasi tidak signifikan. Didukung dengan nilai probabiliitas yang diperoleh adalah 0,115 yang jumlah tersebut lebih besar dari 0,05. Dapat diketahui bahwa hipotesa kerja ditolak dan hipotesa nihil diterima sehingga dalam penelitian ini disimpulkan bahwa tidak ada hubungan antara dukungan sosial dari orang tua sebagai variabel $X$ dengan penyesuaian diri santri remaja sebagai variable $\mathrm{Y}$.

Arikunto, S. 2005. Manajemen Penelitian. Jakarta: Rineka Cipta.

Asmar. 1993. Kumpulan Do'a-Do'a Pilihan untuk Anak-Anak. Surabaya: Penerbit Indah.

Azwar, Saifuddin. 2007.Metode Penelitian. Yogyakarta : Pustaka Pelajar

Azwar, Saifuddin. 2007.Reliabilitas dan Validitas. Yogyakarta : Pustaka Pelajar.

Azwar, S. (2008). Sikap Manusia; Teori dan Pengukurannya. Yogyakarta: Pustaka Pelajar.

Buku Panduan Mata Kuliah Tes Inventory. Fak. Psikologi Universitas Islam Negeri Maulana Malik Ibrahim Malang.

Bungin, Burhan. 2005. Metodologi Penelitian Kuantitatif. Jakarta : Kencana Prenada Media 
Group.

Citra, A.K.S. 2010 Hubungan anatara Dukungan Sosial dengan Psychological Well Being Siswa di SMA Diponegoro Tulungagung. Skripsi Fakultas Psikologi Universitas Islam Negeri Maulana Malik Ibrahim Malang.

Dagun,Save. 2003. Psikologi keluarga .Jakarta: Rineka Cipta.

Desmita. 2009. Psikologi Perkembangan. Bandung: PT Remaja Rosdakarya.

Daradja, Zakiah. 1995. Remaja Harapan dan Tantangan.Jakarta : Ruhama.

Departemen Agama Republik Indonesia. 1989. Al qur'an dan Terjemahannya. Surabaya: Jaya Sakti.

Fathoni, Abdul Halim. 2008. Hikmah Memetik Buah Kehidupan di Kebun Hikmah. Jogjakarta : Darul Hikmah.

Hafi Anshari. 1996. Kamus Psikologi. Surabaya

: Usaha Nasional.

Hartinah, sitti. 2008. Perkembangan Peserta

Didik. Bandung: Refika Aditama

Hasan, iqbal. 2004. Analisis Data Penelitian Dengan Statistik. Jakarta : Bumi Aksara.

Hasan, iqbal. 2002. Pokok-Pokok Materi Metodologi Penelitian dan Aplikasinya. Jakarta : GHIm.ia Indonesia.

Hurlock, Elizabeth. 2003. Psikologi Perkembangan Suatu Pendekatan Sepanjang Rentang Kehidupan. Jakarta : Penerbit Erlangga

Irnawati, D.F. 2009. Hubungan antara Dukungan Sosial Orang tua dengan Prokrastinasi Akademik dalam Menyelesaikan Skripsi pada Mahasiswa Fakultas Psikologi Universitas Diponegoro Semarang. Skripsi Fakultas Psikologi Universitas Diponegoro Semarang.

Isnani, K. .2009. Pengaruh Kematangan Pribadi terhadap Penyesuaian Diri Remaja Siswa SMA Islam Al Ma'arif. Skripsi Fakultas Psikologi Universitas Islam Negeri Maulana Malik Ibrahim Malang.

Kosasih, E. 2002. Kompetensi Ketatabahasaan. Bandung: Yrama Widya.

Lubabinin, F.2008. Pesantren Sebagai Bengkel Moral, Optimalisasi Sumber Daya Pesantren untuk Menanggulangi Kenakalan Remaja. Psikolslamika, Jurnal Psikologi Islam.

Mappiare, andi. 1882. Psikologi Remaja. Surabaya : Usaha Nasional.

Santrock, J. W. 2002. Life-Span Development; Perkembangan Masa Hidup. Jakarta: Erlangga.

Sobur, alex. 2003. Psikologi Umum. Bandung: CV Pustaka Setia.

Suri, M.S. 2009. Pengaruh Dukungan Sosial dari Keluarga terhadap Penyesuaian Diri di Masa Pensiun pada Pegawai Negeri Sipil. Skripsi, Fakultas Psikologi Universitas Sumatera Utara.

Tizar, R. 2010. Pengaruh Dukungan Sosial terhadap Hardiness Remaja di Panti Asuhan Putra Muhammadiyyah Kota Malang. Skripsi Fakultas Psikologi Universitas Islam Negeri Maulana Malik Ibrahim Malang.

Qomar, Mujamil. 2002. Pesantren dari Transformasi Metodologi Menuju Demokratisasi Institusi. Jakarta : Erlangga. 